BENM 2021

International Scientific and Practical Conference "Biotechnology, Ecology, Nature Management"

\title{
THE RECLAMATION OF LANDSCAPES BY INCREASING THE BIOLOGICAL PRODUCTIVITY OF WATER BODIES
}

\author{
I. A. Pasko (a)*, A. V. Gorbunov (b), I. A. Glebova (c), V. A. Barbashov (d) \\ *Corresponding author
}

(a) Individual entrepreneur Pasko Igor Viktorovich, ipasko@inbox.ru

(b) K.G. Razumovsky Moscow State University of Technologies and Management (the First Cossack University), 73, Zemlyanoy Val str., Moscow, Russia

(c) K.G. Razumovsky Moscow State University of Technologies and Management (the First Cossack University), 73, Zemlyanoy Val str., Moscow, Russia

(d) K.G. Razumovsky Moscow State University of Technologies and Management (the First Cossack University), 73, Zemlyanoy Val str., Moscow, Russia

\begin{abstract}
Agroforestry improvement of agricultural landscapes is considered today as an important state task, the solution of which, in combination with other types of reclamation and agrotechnical methods, can ensure the preservation and restoration of soil fertility and environmental sustainability of territories. The analysis performed allows us to assert that the currently used set of solutions does not proceed from a single biosafety concept for the agrarian biogeocenoses themselves and their natural components that determine the natural capacity of the territory (buffer ecological capacity of the territory). Methods of analysis, deduction, generalization were applied. This article formulates some important features and conceptual approaches to the reclamation of agricultural landscapes, by increasing the biological productivity of inland water bodies with progressive biotechnological methods, and introducing a biological certification system for agroecosystems, based on a new integrated approach. Its implementation can be carried out at the level of adopting a compulsory system of biological certification, including a new qualitative block "for eco-bio-conformity", with the use, in some cases, of an appropriate expert assessment. Such a systemic interconnected approach in complex agrobiolandscape areas. how: preservation and maintenance of these territories from the standpoint of not only bio- or only agrocenoses, but as agrobiocenoses, including its multicomponent qualitative development in the direction of increasing bioproductivity and unity with the natural environment through aquatic hydrobiosystems and individual local water bodies - seems harmonious and promising fundamental in agricultural and reclamation activities of the future.
\end{abstract}




\section{Introduction}

By the program of long-term development of MGUTU, for the period up to 2027, the direction "Biomelioration of agricultural landscape territories by increasing the bioproductivity of reservoirs of complex and agricultural purposes" is highlighted as promising and innovative, and, today, together with industrial fish farming, is one of the priorities. This scientific problem, namely biological reclamation and reclamation of aquatic and various landscape ecosystems at the University for a long time, due to its professional interests, has been dealt with by the Institute of Biotechnology and Fisheries (BiRH) (Decree of the Government of the Russian Federation of February 20, 2006 N 99, 2021).

For research purposes, general scientific research methods were applied, adapted to the topic: analysis, deduction, generalization, as well as some special methods - the method of multipurpose analysis, which are determined by the nature of the research, the set goals and objectives

Analysis of the current state and possible scenarios for the development of agricultural production confirms the need for a set of measures to stabilize and restore agricultural land, ensuring an increase in soil fertility of agricultural lands, as well as an improvement in the overall environmental situation.

Agricultural lands that have been retired over the past 15 years amounted to more than 15 million hectares, more than 56 million hectares of arable land are characterized by a low humus content. The average annual deficit of humus in the arable layer in recent years in the Russian Federation averaged 0.52 tons per hectare. The applied doses of mineral and organic fertilizers do not compensate for the loss (during harvesting) of soil nutrients (Decree of the Government of the Russian Federation of February 20, 2006 N 99, 2021).

Protective forest plantations are the basis of landscape agriculture, its ecological framework. In order to obtain the maximum effect from protective afforestation, as a rule, it is envisaged to create forest plantations, including field-protective forest belts, anti-erosion ravine and ravine plantations, and pastureprotective phyto-meliorative plantations.

In accordance with the current regulations, each hectare of field protection forest belt protects 120 hectares of agricultural land (agroecosystems) and their biological products, a hectare of anti-erosion plantations - 10 hectares of agricultural land, and each hectare of pasture protection plantations - 15 hectares of agricultural land. Therefore, it is necessary to periodically carry out clearing in protective forest plantations of I-V age classes and to reconstruct existing forest plantations of protective and local ecotones, which will allow protecting a significant amount of agricultural land (GOST R 58330.2-2018, 2019).

Further degradation and retirement of agricultural land from circulation can lead to a complete stagnation of agricultural production.

\section{Purpose of the Study}

The Federal Target Program "Preservation and restoration of soil fertility of agricultural lands and agricultural landscapes as a national treasure of Russia for 2006-2010 (Resolution of February 20, 2006 No. 99) and for the period up to 2013" provided a set of measures aimed at preserving, restoring and 
reproduction of soil fertility through the construction and reconstruction of reclamation and water management facilities.

Based on the results of the implementation of this FTP (Results of the implementation of the Federal Target Program..., 2011), a number of established indicators were achieved, as well as, the VNIIESKh institute developed a methodological base for the rational use of agricultural land, taking into account the biological characteristics of crops, agro-ecological, economic and resource constraints in various regions of Russia; Institute VNIALMI - methodology and principles of formation of the optimal structure of agroforestry complexes in different zones of the country (Decree of the Government of the Russian Federation of February 20, 2006 N 99, 2021).

\section{Findings}

Based However, it should be noted that the constituent elements of soil fertility preservation for agricultural lands are very multifaceted and represent a combination of a wide variety of factors that affect the potential return of agricultural land in the form of a crop. Environmental and biological risks of the implementation of the measures laid down in this program are associated with the following anthropogenic factors:

- violation or change of the scientifically grounded farming system or refusal to carry out agrotechnical measures;

- deterioration of the reclamation and water-air condition of irrigated and drained lands;

- the influence of natural factors (drought, flooding and a sharp change in the level of groundwater);

- land desertification, water and wind erosion;

- safety of functioning of hydraulic structures;

Agricultural irrigation, which is being implemented today, is an improvement in the hydrological regime of agroecosystems, or, in the modern interpretation of agricultural landscapes, by irrigation - or drainage: both of these methods of irrigation are very one-sided and pose a quite definite environmental hazard.

In turn, the conceptual approach to these measures through biological reclamation of water bodies includes a set of measures aimed at improving the living conditions of useful aquatic organisms and artificially increasing the biological and economic productivity of water bodies. So, the drainage of bogs, for example, leads to a change in the general hydrological regime of a territory and transforms them from ecosystems that fix carbon into territories that emit carbon dioxide during peat mineralization, which occurs when it dries out due to aerobic microbiological processes. As you know, drainage caused great damage to the Non-Black Earth Region in the European part of Russia, where thousands of rivers and streams disappeared and a general drying out of the territory began, and the yield of field crops and meadows decreased. In some cases, arable land on drained peatlands turned out to be unproductive (Vronensky, 1996).

It is well known that the expansion of the area of irrigated arable land leads to an increase in water consumption from rivers, which disrupts their hydrological regime and causes the destruction of ecosystems in large areas (desertification occurs in the steppe and desert zones). Hydro-reclamation 
inflicted great ecological and economic damage on the steppe regions of the Trans-Volga region, where millions of hectares of steppe pastures perished as a result of soil salinization. Drainage was also the cause of large fires in the summer of 2010 in Central Russia, which caused significant environmental and economic damage to both people and the economy of many regions of the country (Geoecological principles of designing natural..., 1987).

So today, watering from lakes is prohibited, where interference with the hydrological regime is especially dangerous, since it can lead to irreversible changes in their ecosystems (for example, to the disappearance of fish and water bloom, i.e. the massive development of cyanobacteria, etc.). However, it should be remembered that such reservoirs are found not only in natural biogeocenoses, but also in agricultural landscapes.

The modern legislation defines agrolandscapes (or agrocenoses) as natural-territorial complexes, however, the natural vegetation of which, in the overwhelming part, has been replaced by agrocenoses. Agrocenoses, like any natural ecosystems, have a certain composition of organisms (cultivated plants, weeds, insects, earthworms, murine rodents, etc.) and certain relationships between living organisms and environmental conditions (Gorbunov et al., 2013).

These relationships are most clearly manifested at the level of trophic links between organisms, which are exactly disturbed during intensive farming and appropriate reclamation measures that do not organically link all this into a single whole. For this reason, the ecological stability of agrocenoses is low; they are incapable of self-regulation and self-renewal, are subject to the threat of death during the mass reproduction of pests or pathogens (Nikishin et al., 2014).

In agroecosystems, the species diversity of living organisms is also sharply reduced. One or more species (varieties) of plants are usually cultivated in the fields, which leads to a significant depletion of the species composition of animals, fungi, and bacteria. In addition, the biological uniformity of varieties of cultivated plants occupying large areas (sometimes tens of thousands of hectares) is often the main reason for their mass destruction by specialized insects (for example, the Colorado potato beetle) or damage by pathogens (powdery mildew, rust, smut fungi, late blight, etc. etc.). Thus, it is necessary to carry out a timely comprehensive bioremediation of these objects.

Biological reclamation of water bodies is the development of a set of targeted measures aimed at restoring depressed and degraded aquatic ecosystems, incl. on worked-out peatlands, using biological means and environmentally friendly methods, their useful properties and qualities disturbed by human economic activity.

In biomelioration and bioremediation of aquatic systems and shallow reservoirs, in the classical approach, the introduction of herbivorous fish (grass carp, silver carp and silver carp, etc.) into reservoirs is also used in order to combat overgrowth of reservoirs (ponds, reservoirs, canals, etc.) (Nikishin et. al., 2014).

The technologies of biomelioration and bioremediation, both in their classical form and in their new modern forms, seem to us especially relevant and promising, since in this case, a stable tendency is revealed to restore the ecological balance of natural and natural ecosystems, as well as agricultural land, disturbed by the industrial society. , due to a number of complex measures to preserve and increase their natural biological productivity. At the same time, the implementation of agroforestry and water protection 
measures to preserve and restore (increase the bioproductivity) of water resources, incl. due to agricultural and fishery use (Nikishin et. al., 2014).

At the same time, in order to manage the processes of transition to sustainable development and assess the effectiveness of the resources used, it is necessary to set targets and limits with the provision of a procedure for monitoring their achievement (compliance). Target benchmarks can be expressed in terms of indicators characterizing the quality of agroecosystems (bioproductivity) and its ecological and biological well-being (for example, natural resource capacity) (Decree of the President of the Russian Federation of 01.04.1996 N 440, 2021).

A system of indicators characterizing the level of consumption of natural resources and the level of disturbance of ecosystems as a result of economic activity (per unit of cultivated agricultural area, or final product) could serve as indicators that determine the degree of nature intensity of the economy. Informative in this issue are also macrocharacteristics expressing the relationship between the needs for natural resources and their availability (reserves) (Geoecological principles of designing..., 1987).

In accordance with the existing GOST, the system of hydro-forestry reclamation measures should include the following functional parts: reclamation, transport, operational, fire-fighting, biotechnical. With regard to the biotechnical part, in our opinion, it is necessary to be guided by the fact that for agroand natural biosystems, where the main difference lies in a different balance of nutrients, it is obvious that this balance must be both maintained and stimulated and optimized in every possible way without disturbing natural natural processes (GOST 26462-1985, 1986).

In a natural biogeocenosis, the primary production of plants (crops) is consumed in numerous chains (networks) of food and again returns to the biological cycle in the form of carbon dioxide, water, and elements of mineral nutrition. In the agrocenosis, such a turnover of elements is sharply disturbed, since a significant part of them is removed by a person with a harvest. Therefore, in order to compensate for their losses and, consequently, to increase the productivity of cultivated plants, it is necessary to constantly apply various fertilizers to the soil.

Thus, in comparison with natural biogeocenoses, agrocenoses have a very limited species composition of plants and animals, they are not capable of self-renewal and self-regulation, are subject to the threat of death as a result of mass reproduction of pests or pathogens and require tireless and regular activity to maintain them (Nikishin et. al., 2014)

I. In this regard, the promising biomeliorative directions developed by the BiRH Institute seem to be relevant, first of all, these are:

II. Phytoremediation of aquatic systems - development of a complex of methods for purification of waters, bottom and coastal soils using green and aquatic plants, based on phytostimulation of fauna (inclusion of biotechnologies to stimulate the development (creation) of symbiotic microorganisms that are directly involved in the process of cleaning a reservoir).

III. Bioremediation of water systems - development of advanced biotechnologies, methods of purification and detoxification of polluted waters and coastal soils using microorganisms. In general, the bioremediation technological process of water purification is the splitting of complex organic compounds by microorganisms and their transformation into simple mineral compounds that are not soluble in water. A verified methodology for combining, dosage and types of aerobic and anaerobic 
processes, allows you to achieve the most optimal results, incl. on existing reservoirs. As a result of the application of these microorganismic biotechnologies, the ecological balance of stagnant water bodies is restored, with the creation of the possibility of their effective fishery use, which is extremely important for small businesses and farms.

A complex of specialized problems, directly related to the quality indicators of reclamation measures, is fundamentally important: environmental and food toxicological safety of both agricultural and livestock products, and the fodder base, as well as with the preservation and increase of the biological productivity of water bodies in agricultural landscapes. These, first of all, include:

1) Increasing the productivity of domestic agricultural production, its greening;

2) Maintenance and optimization of hydrological characteristics of agricultural landscapes;

3) Development of measures to optimize hydraulic systems in order to increase the biological productivity of agricultural landscapes;

4) Development of biotechnologies and biotechnical means of biological reclamation.

5) Biological safety of ichthyofauna and hydrocenoses, during the functioning of hydraulic structures;

6) Ecological and toxicological examination of water bodies and hydraulic systems in agricultural landscapes;

7) Biological expertise of project reclamation measures in order to preserve and optimize the state of the environment;

8) Bioresource assessment and biological optimization of reclamation hydraulic systems;

9) Increasing the productivity of domestic agricultural production, its greening;

10) Maintenance and optimization of hydrological characteristics of agricultural landscapes;

11) Development of measures to optimize hydraulic systems in order to increase the biological productivity of agricultural landscapes;

12) Development of biotechnologies and biotechnical means of biological reclamation.

13) Comprehensive solution of issues of rational use and reproduction of water resources in reservoirs on agricultural lands;

14) Biological cleaning of hydraulic structures (water intakes, regulating structures, waterways) from fouling with blue-green algae;

15) Realization of the biological potential of the productivity of water bodies on agricultural lands, taking into account their degradation processes;

The need to form a new comprehensive legislative approach in this area is also seen as extremely important:

- to reclamation activities - as harmless and eco-friendly;

- to reclaimed objects - as providing (non-limiting) the effective bioproductivity of natural biosystems, due to the maintenance and development of natural aquatic ecosystems;

- to agricultural production - as a harmonious and natural process of obtaining not only high-quality plant products, but also products of animal origin, including fish and phyto products, linked to the fulfillment of recreational tasks for the population. 


\section{Conclusion}

Its implementation can be carried out at the level of adopting a compulsory system of biological certification, including a new qualitative block "for eco-bio-conformity", with the use, in some cases, of an appropriate expert assessment. Such a systemic interconnected approach in complex agrobiolandscape areas. how: preservation and maintenance of these territories from the standpoint of not only bio- or only agrocenoses, but as agrobiocenoses, including its multicomponent qualitative development in the direction of increasing bioproductivity and unity with the natural environment through aquatic hydrobiosystems and individual local water bodies - seems harmonious and promising fundamental in agricultural and reclamation activities of the future.

To ensure the possibility of solving the above-mentioned tasks in this highly sensitive area, it is necessary to develop and adopt appropriate documentation, for example, a Concept, a Strategy - where an integrated vision of this issue will be indicated, both existing and new approaches to agricultural land reclamation are identified and interconnected, taking into account the new for it biological component, priority targets have been identified; after that, the legislative base of the federal and regional levels should be finalized and adapted.

\section{References}

Decree of the Government of the Russian Federation of February 20, 2006 N 99. (2021). "On the federal target program" Preservation and restoration of soil fertility of agricultural lands and agricultural landscapes as a national treasure of Russia for 2006 - 2010 and for the period until 2013 "(with amendments and additions).

Decree of the President of the Russian Federation of 01.04.1996 N 440. (2021). "On the Concept of the Transition of the Russian Federation to Sustainable Development" of 01.04.1996 N 440

Geoecological principles of designing natural and technical geosystems. (1987). Institute of Geography of the Academy of Sciences of the USSR.

Gorbunov, A. V., Gorbunov, O. V., Borodin, A. L., \& Ridiger, A. V. (2013). Characteristic features of freshwater ichthyocenosis of a model reservoir of a regulated type. Fish industry, 4, 74-77.

GOST 26462-85. (1986). Agroforestry. https://docs.cntd.ru/document/1200023261

GOST R 58330.2-2018. (2019). Land reclamation. Types of reclamation activities and works. Classification. https://docs.cntd.ru/document/1200161976

Nikishin, A. L., Gorbunov, A. V., \& Sechin, Y. T. (2014). Problems of restoration and development of fisheries in inland waters / zh-1 "Fisheries" TSUREN.

Results of the implementation of the Federal Target Program "Conservation and restoration of soil fertility of agricultural lands and agricultural landscapes as a national treasure of Russia for 20062010 and for the period until 2012": (2011). Analytical information on the implementation of the federal target program. Ministry of Agriculture of the Russian Federation.

Vronensky V. A. (1996). Applied ecology. Nauka. 